The Ideology of Jokowi as Indonesian President in Critical Discourse Analysis Study (Elizabeth Septiani Munandar, Indah Arvianti, Ahmad Muhid)

\title{
THE IDEOLOGY OF JOKOWI AS INDONESIAN PRESIDENT IN CRITICAL DISCOURSE ANALYSIS STUDY
}

\author{
Elizabeth Septiani Munandar'), Indah Arvianti, S.S, M.Hum. ${ }^{2)}$ \\ Ahmad Muhid, S.S, M.Hum ${ }^{3)}$ \\ Language and Culture Faculty, AKI University \\ Email: lizsepti@gmail.com, indah.arvianti@unaki.ac.id,ahmad.muhid@unaki.ac.id
}

\begin{abstract}
People as social human beings need a language for communication in daily activities. Communication can be found in many forms, one of them is speech. Thus, related to speech and the function of the speech to society the writer is interested in analysing the language, power and ideology in the speech of President Jokowi's. This study uses critical discourse analysis theory, where it can be found that ideology can be revealed with the use of vocabulary, grammar and text structure of the speaker. The writer uses qualitative method by analysing Jokowi's speech transcript. The writer also uses identity method by applying sociolinguistics method and pragmatic method. For presenting the data, the writer uses informal method. The writer found eight ideologies in analysing Jokowi's speech such as the ideology of equality, the ideology in unity, the ideology to honour the law, the ideology of social justice, the ideology in prioritizing citizen, the ideology of national prosperity, the ideology of hard working, and the ideology in assertiveness. The result of this study shows a proof about the relationship between language, power, and ideology. As an Indonesian president, Jokowi has the power to choose the utterance in his speech. Through power over language, Jokowi can reveal the ideology that he holds so that the citizens can understand and follow his ideology.
\end{abstract}

Keywords: Critical Discourse Analysis, Language, Power, Ideology

\section{Introduction}

People as a social human being need a language for communication in everyday activities. This activity can appear in verbal and non-verbal form. Non-verbal communication can be found in the form of books, novels, articles, advertisements and newspapers. Meanwhile, verbal communication can be found in spoken between people, interview, phone calls, speech, etc.

Speech is a form of public speaking activity that is used in formal event. The importance of speech is not only applied for people in general but also important for the government because it can be used as a tool to control and discipline the society. One of the government leaders who seems to use speech for communication with people is President Joko Widodo. As a president, Jokowi is still being doubted as the leader of Indonesia even though he takes the president title. Some people still distrust his voice and his ability to represent and lead the citizens. He is likely seen as the face that represents parties rather than representatives of the whole citizens. 
In using speech, we can see the use language by Jokowi and how it can form an idea about power and ideology. To study the use of language and the reason why the language used in that technique, the writer will investigative the context using critical discourse analysis approach which is one of the studies to understand the connection between language, power, and ideology.

Thus, related with speech and the function of the speech to society the writer is interested to analyse the language, power and ideology in the speech of President Jokowi. The language, power and ideology can be seen from the use of the speech to resolve the social problem at that time.

\section{Theoretical Framework}

This study uses discourse theory in which Schiffrin (1994, p. 41) views as a part of language construction whether it is spoken or written that naturally contextualized and elude the problem how language in utterance is related to sentences. The type of discourse in this study is taken from speech.

To analyse the discourse, it is connected with discourse analysis theory. In discourse analysis, we study about analysing linguistic issues that focuses on spoken or written activities by emphases language used in the context to express some intention. It can be concluded that discourse analysis is related with power and dominance in the context.

Thus, because discourse analysis is connected with power in discourse and power in society then it is related with analysing between language, power and ideology. In order for someone to use language, he/she must have shown the power that they hold within others and it can explain about the ideology they own.

Furthermore, the study uses the theory of critical discourse analysis by Fairclough where it can be stated as text or talk that produced to shows power or dominance due to social problem in society. In Fairclough dimension of critical discourse, he explain how discourse as a social process is produce. He analyse how a text is produced and how that text is interpreted. Meanwhile, language which is connected with the context as a social culture practice is related with dimension such as social situation, institution and culture.

Moreover, to reveal the ideology this study uses lingual device using vocabulary (by analyzing metaphor, the use of positive and negative words, euphemism, formal and informal words, word reference, expressive words and lexical process), grammatical (transitive, passive 
The Ideology of Jokowi as Indonesian President in Critical Discourse Analysis Study (Elizabeth Septiani Munandar, Indah Arvianti, Ahmad Muhid)

and active sentences, positive and negative sentences, declarative, imperative and declarative sentences, rational modality, pronominal persona, conjunction and expressive modality) and textual structure (by using interaction features).

\section{Research Methods}

\subsection{Research Design}

Research method is very important in research study to do investigation. In this study uses qualitative method with datum that are taken from Jokowi's speech. Qualitative method itself according to Djam'an (2010, p. 12) "refers to the meaning, concept, definition, characteristics, metaphors, symbols, and descriptions of things."

\subsection{Method of Data Collection}

For data collection, the writer uses observation method and introspection method. The observation method that the writer uses are Teknik Simak Bebas Libat Cakap in which the writer only observe the language used by the informant and will not involve directly in the event, and Teknik Catat in which the data gathered from the informant will be written down in a note.

Thus, in this part of data collection, firstly the writer will observe the data taken from video in YouTube. Then, the writer will make a note about the data that later will be used to analyse this study.

The writer also uses introspection method in addition to help investigating the data by using the writer's intuition to understand the language used.

\subsection{Method of Data Analysis}

Next, for method data analysis, the writer uses distributional method with using teknik ulang to show the repetition of the units, teknik baca markah to read symbols that attached in the data and metode reflektif-introspektif to understand explain and identify the data. Lastly, the writer uses identity method using sociolinguistic method and pragmatic method. By using sociolinguistic the writer can interpret the meaning of the speech and the function it has in relation with society as a part of social aspect and by using pragmatic method the writer can see the meaning of the utterance in some certain context and to see the reaction it has to the listener as speech partner. 


\section{DISCUSSION}

\subsection{The Ideology of Equality}

\section{Data 1}

"Yang pertama yang ingin saya sampaikan sekali lagi ini saya perlu saya ulang bahwa tidak ada visi misi menteri. Yang ada visi misi presiden dan wakil presiden. Ini tolong dicatat karena dalam 5 tahun yang lalu ada satu, dua, tiga menteri yang masih belum paham mengenai ini.” (https://www.youtube.com/watch?v=cRFsadD_IE\&feature=youtu.be)

The data above shows the ideology of equality. In the utterance, we can see in the language used that there is a morpheme "tolong" (help). According to Kamus Besar Bahasa Indonesia, the morpheme "tolong" means Bantu: minta (https://kbbi.web.id/tolong). In this context, the morpheme "tolong" (help) means "please" because it is a form of asking for a help. This is a form of euphemism because even though Jokowi is a president who has a power over society, he still prefers to use the morpheme that is not directly order someone to do as he pleased but rather he chose the morpheme that make it seems like he is not having higher-up status.

Data 2

"Saya sering mengingatkan kepada para menteri, tugas kita bukan hanya membuat dan melaksanakan kebijakan, tetapi tugas kita adalah membuat masyarakat menikmati pelayanan, menikmati pembangunan.” (https://nasional.kompas.com/jeo/naskah-lengkappidato-presiden-joko-widodo-dalam-pelantikan-periode-2019-2024)

The text structure shows the morpheme "mengingatkan" (remind) which comes from root "ingat" (remember) and given prefix "men-" and suffix "-kan". The morpheme "ingat" (remember) itself has a meaning of berada dalam pikiran, tidak lupa, timbul kembali dalam pikiran, sadar, menaruh perhatian, etc (https://kbbi.web.id/ingat). It is a morpheme where the context of the morpheme display the means to remembering something so the speech partner will not forget about the speaker's message.

We can also see the morpheme has a prefix "men-" that has a meaning to do something repeatedly and the suffix "-kan" which has a function to shows action that intended for other people. In this context, Jokowi is using politeness because the morpheme "mengingatkan" has 
The Ideology of Jokowi as Indonesian President in Critical Discourse Analysis Study (Elizabeth Septiani Munandar, Indah Arvianti, Ahmad Muhid)

the purpose to remind the minister about their duty for the citizen. He wants everyone to know that action he has done it repeatedly by the use of affixes and by the use of morpheme "sering" (often). The president tries to make it less offending for the minister because even though he often tells the minister about their duty he wants to make it more polite by using morpheme remind rather than just demand the minister to fulfill their duty.

In politeness, there are three factors which affects its usage. The factors are: power, social distance and weight of imposition. In this analysis, power does not have a strong influence over the language used. This happens because as a president, Jokowi has a power over the minister to elect and discharge them. Thus, power cannot be said as the factor that effect the use of politeness.

Moreover, social distance also has less impact on the morpheme picked. Social distance between president and minister is very close. They both have a position on the government and have the ability meet and share opinion together. Because of that, the social distance can be said to be having no factor towards the preference to use politeness.

Weight of imposition on the other hand seems to be the main factor which underlie the use of politeness. In his speeches, president Jokowi mostly asked the speech partner to do something. To make them wants to follow the president direction and obey, president Jokowi uses polite sentences. This factor also influenced by the level of difficulty to complete the task. If the difficulty level of the task is higher, then the language used will be more polite.

We can see the pragmatic method from the speech in the reaction by the minister when they obey Jokowi's direction. From this, we can also see that Jokowi's intention and meaning of the speech is reached.

\subsection{The Ideology in Unity}

\section{Data 3}

"Saya sering mengingatkan kepada para menteri, tugas kita bukan hanya membuat dan melaksanakan kebijakan, tetapi tugas kita adalah membuat masyarakat menikmati pelayanan, menikmati pembangunan.” (https://nasional.kompas.com/jeo/naskah-lengkappidato-presiden-joko-widodo-dalam-pelantikan-periode-2019-2024)

Other ideology also can be found from the data above. From the data, we can see that Jokowi also shown his ideology of unity by using the morpheme "kita" (us). The use of morpheme "kita" support the ideology of unity because as shown in KBBI, the morpheme "kita" 
means "pronominal persona pertama jamak, yang berbicara bersama dengan orang lain termasuk yang diajak bicara" (https://kbbi.web.id/kita). The morpheme "kita" (us) refers to the audience and the speaker himself. Thus, in this data we can see that the president wants to states that he is a part of the society as the addressee of his speech. He does not want other people to take responsibility of the job alone but he wants to take the responsibility. He wants to show others that he sees himself as someone who also has responsibility over the task and not just let other people do the task as he ordered.

Data 4

"Assalamualaikum warahmatullahi wabarakatuh, selamat sore, salam sejahtera bagi kita semuanya, om swastyastu, namo buddhaya, salam kebajikan." (https://nasional.kompas.com/jeo/naskah-lengkap-pidato-presiden-joko-widodo-dalampelantikan-periode-2019-2024)

Indonesia is a country that consist of many cultures and ethics and also religions. According to Indonesian government's data, there are 6 religions in Indonesia which are Moslem with $87,2 \%$, then Christian with 6,9\%, Catholic with 2,9\%, Hindu 1,7\%, Buddha 0,7\% and Khonghucu with $0,05 \%$. The number shows that the majority of Indonesia citizen's religion is Moslem, but other religions are still exist and their existence needs to be recognized and cared for.

The data above shows that Jokowi has this viewpoint about respect and equality for all Indonesia citizen with different religions. The data shows that the greeting that the president uses representing all the religion in Indonesia. To make it clearer the data is explained in the table below:

Table 1

Objective in Greeting

\begin{tabular}{|l|l|}
\hline \multicolumn{1}{|c|}{ Greeting } & \multicolumn{1}{|c|}{ Addressee } \\
\hline $\begin{array}{l}\text { Assalamualaikum warahmatullahi } \\
\text { wabarakatuh }\end{array}$ & Moslem \\
\hline salam sejahtera bagi kita semuanya, & Christian and Catholic \\
\hline om swastyastu & Hindu \\
\hline namo buddhaya & Buddha \\
\hline salam kebajikan & Khonghucu \\
\hline
\end{tabular}


The Ideology of Jokowi as Indonesian President in Critical Discourse Analysis Study (Elizabeth Septiani Munandar, Indah Arvianti, Ahmad Muhid)

selamat sore

General Public

The data in the table confirm that the president uses greeting addressed to all people. The greeting that Jokowi uses during his speech expressed his respect to all different religion in Indonesia. As the Indonesia's slogan "Pancasila" (five principles) which is "Bhineka Tunggal Ika" (unity in diversity) the president wants to shows that he valued all of Indonesian citizen and wants to give an example to the citizen to always respect all people.

\subsection{The Ideology to Honor the Law}

\section{Data 5}

"Ya kalau ada yang ndak bener ya diproses hukum saja. kita semuanya menghormati proses hukum yang ada di KPK. Kita semuanya harus menghormati proses hukum yang ada di KPK! dan saya yakin KPK bekerja sangat professional dalam memproses semua kasus." (https://www.youtube.com/watch?v=ekweEZcQ1As\&feature=youtu.be)

\section{Data 6}

"Saya menghormati proses hukum yang sedang berjalan di KPK terhadap siapapun. ”(https://www.youtube.com/watch?v=zr6ZQQ4Inao\&feature=youtu.be)

The two main focuses of the utterance above are to tell the people that Jokowi trusts the law and he respects the law. In data 5, the subject who causes the riot is ordinary citizen. Meanwhile in data 6, the subject who does wrong doing is Jokowi's brother in law. In these two cases, they all commit wrong thing and Jokowi states in both cases that the law will take an action. This act performs regardless of the status that the subject has. While the citizen with no status can be threatened by law, the subject in data 6 who has a status as Jokowi's brother in law also can be threatened by law. This decision is based on the idea to construct stability of the situation where Indonesians agree to no tolerate wrong action as it will immediately be treated with applicable law.

\subsection{The Ideology of Social Justice}

\section{Data 7}

"Kita harus bertransformasi dari ketergantungan pada sumber daya alam menjadi daya saing manufaktur dan jasa modern yang mempunyai nilai tambah tinggi bagi kemakmuran bangsa, demi keadilan sosial bagi seluruh rakyat Indonesia.” 
(https://nasional.kompas.com/jeo/naskah-lengkap-pidato-presiden-joko-widodo-dalampelantikan-periode-2019-2024)

In this part of the speech, the ideology of social justice is clearly shown because Jokowi stated it in the last clause of the speech "demi keadilan sosial bagi seluruh rakyat Indonesia" (due to the social justice for all Indonesia citizen). The prominence of the sentence means that this part is important to him because he stated it directly in his speech on presidential inauguration day. Thus, social justice is one of the ideology which Jokowi has and wants citizen to know the importance of it.

\subsection{The Ideology in Prioritizing Citizen}

Data 8

"Bagi yang tidak serius, saya tidak akan memberi ampun. Saya pastikan, sekali lagi saya pastikan, pasti saya copot.” (https://nasional.kompas.com/jeo/naskah-lengkap-pidatopresiden-joko-widodo-dalam-pelantikan-periode-2019-2024)

The utterance appears in the form of declarative sentence. Declarative sentence is a sentences which states statement. It usually uses in a political sentences because it can describe things that make a definite statement. This types of phrase also put the perspectives of people that Jokowi is in citizen's side rather than the parties. The utterance shows cause and effect. If the officials are not "serius" (serious) in doing their duty, the action that will be performed due to that matter is that the president Jokowi will have to demote them from their position in the government. We can also see that the clause "sekali lagi saya pastikan," (,once more I make sure,) is enclosed in commas. In this context, Jokowi claims that he will ensure to remove government member who does not carry out their duty and the clause in between commas is stated to emphasize this statement. There is also the repetition of the morpheme "pasti" (certainly). This is highlighting the belief that Jokowi will definitely take an action where he will demote the officials no matter their status because he has the power to do so. Thus, the objective in the action is to show the citizen that he puts the citizen's priority over the governors.

\subsection{The Ideology of National Prosperity}

Data 9

"Kita harus bertransformasi dari ketergantungan pada sumber daya alam menjadi daya saing manufaktur dan jasa modern yang mempunyai nilai tambah tinggi bagi 
The Ideology of Jokowi as Indonesian President in Critical Discourse Analysis Study (Elizabeth Septiani Munandar, Indah Arvianti, Ahmad Muhid)

kemakmuran bangsa, demi keadilan sosial bagi seluruh rakyat Indonesia. ”(https://nasional.kompas.com/jeo/naskah-lengkap-pidato-presiden-jokowidodo-dalam-pelantikan-periode-2019-2024)

In the data above, there is a hint of Jokowi's perspective to make the nation prosperous. He says it in the clause "jasa modern yang mempunyai nilai tambah tinggi bagi kemakmuran bangsa" (modern service that have high value for the nation's prosperity). The clause clearly stated about the aim Jokowi has for Indonesia which is to make the nation prosperous "bagi kemakmuran bangsa". This ideology is also one of the main ideology because it is hinted continuously and repeatedly throughout Jokowi's speech. The national prosperity is something that Indonesia has been struggle with for a very long time. As a developing country, national prosperity is not easy to reach because of many aspect factors. One of the factors is the total population of the citizen. The increasing population means that it will impacting social instability. This has an effect on employment and the government social welfare.

\subsection{The Ideology in Hard Working}

\section{Data 10}

"Namun, semua itu tidak datang otomatis. Tidak datang dengan mudah. Harus disertai kerja keras dan kita harus kerja cepat. Harus disertai kerja-kerja bangsa kita yang produktif. "(https://nasional.kompas.com/jeo/naskah-lengkap-pidato-presiden-joko-widododalam-pelantikan-periode-2019-2024)

From what the writer has gathered throughout this analysis to make people can comprehend Jokowi's ideology and for this idea to implant in people's mind, he uses the repetition of morpheme for the idea that he believes. He wants to make sure that the citizen and government can understand his perspectives and his idea and for the people to have the same ideology as him. Moreover, this ideology becomes the one ideology that Jokowi tries to display in a lot of occasion. From a small speech to the speech in presidential inauguration. In many occasions, this ideology is easy to find.

\section{Data 11}

"Saya ingin menyampaikan beberapa hal yang harus kita ketahui bersama terutama yang akan kita kerjakan, kerja kerja besar yang akan kita lakukan dalam 5 tahun kedepan."(https://www.youtube.com/watch?v=cRFsadD_I-E\&feature=youtu.be) 
As a president, Jokowi realizes that problem. Thus, he persuades the people to work together. Therefore, in the data above, the work includes everyone. That idea is concluded from the used of morpheme "kita" (us) which aims to the government and the citizen, because he has the power to addressed both sides to do the work together.

This Ideology in hard work is the reflection of Jokowi's background as a hard worker. At the early age he already worked in his father's furniture shop. The relationship between roles and background makes Jokowi the leader who has an ideology that accentuates hard work. This is the reason that makes hard work to be one of the ideology the writer wants to acknowledge.

\subsection{The Ideology in Assertiveness}

\section{Data 12}

"Yang berkaitan dengan Natuna. Saya kira seluruh statement yang disampaikan sudah sangat baik bahwa tidak ada yang namanya tawar menawar mengenai kedaulatan mengenai territorial negara kita."

(https://www.youtube.com/watch?v=w7Qlqj1_7MY\&feature=youtu.be)

The context from two of the data above is the situation in Indonesia when our fisherman cannot take the fish in our sea territorial. There is Jokowi statement "kedaulatan itu tidak bisa ditawar-tawar" (sovereignty is not negotiable). This statement shows Jokowi ideology in assertiveness. He shows bravery over country that does not agree the sea is still in Indonesia's territorial, even though that country is bigger and stronger than Indonesia.

\section{Conclusion}

In his speech, Jokowi uses selection of words that he wants to make the citizens understand about his ideology. This ability is related to the power he owns as a president of Indonesia. Thus, through the power and language Jokowi can put the ideologies that he believes into the citizen's perspectives. Therefore, this Jokowi's ideology analyses which are reflected in his speech are the ideology of equality, the ideology in unity, the ideology to honour the law, the ideology of social justice, the ideology in prioritizing citizen, the ideology of national prosperity, ideology of hard working, and the ideology in assertiveness. The result of the study shows that the text in 
The Ideology of Jokowi as Indonesian President in Critical Discourse Analysis Study (Elizabeth Septiani Munandar, Indah Arvianti, Ahmad Muhid)

discourse practice is produced by Jokowi. It is interpreted by the citizen and created some ideologies that the citizen believes to be Jokowi's ideologies.

\section{References}

Arvianti, I. (2011). Seksisme dalam kesantunan bahasa komplain. Jurnal linguistik dan Edukasi PPS Linguistik Undip, 2(1), 26-44.

Arvianti, I. (2016). Buku ajar analisis wacana. Semarang: CV Madina.

Birner, B.J., (2013). Introduction to pragmatics. UK: Blackwell Publishing.

CNN Indonesia. Jokowi: Tidak ada visi \& misi menteri [Video File]. Retrieved (2019, October 24) from https://www.youtube.com/watch?v=cRFsadD_I-E\&feature=youtu.be

Creswell, J.W., (2014). Research Design: Qualitative, quantitative, and mixed methods approaches $\left(4^{\text {th }} \mathrm{ed}\right)$. United States: SAGE.

Djam'an. (2010). In Muhammad, (2011). Metode penelitian bahasa. Jogjakarta: AR-RUZZ MEDIA.

Dosenbahasa.com. Makna akhiran kan dan contohnya dalam kalimat. Retrieved (2019, December 13) from https://dosenbahasa.com/makna-akhiran-kan-dan-contohnya-dalamkalimat

Dosenbahasa.com. Makna imbungan meng dan contohnya dalam kalimat. Retrieved (2019, December 13) from https://dosenbahasa.com/makna-imbuhan-meng-dan-contohnyadalam-kalimat

Education First. (2018). Tanda baca koma. Retrieved from https://www.ef.co.id/panduanbahasa-inggris/tanda-baca-koma/

Fairclough, N. (1989). Language and power. In prof. Christopher N candling (Eds.), Language in social life series. England: Addison Wesley Longman limited.

Indonesia.go.id. Agama [Table]. Retrieved (2019, December 14) from https://indonesia.go.id/profil/agama

Kamus Besar Bahasa Indonesia. Tolong. Retrieved (2019, December 5) from https://kbbi.web.id/tolong

Kamus Besar Bahasa Indonesia. Ingat. Retrieved (2019, December 6) from https://kbbi.web.id/ingat

Kamus Besar Bahasa Indonesia. Kita. Retrieved (2019, December 14) from https://kbbi.web.id/kita 
Kompas TV. Ini Kata Jokowi Soal Kasus Korupsi yang Membelitadik Iparnya [Video File]. Retrieved (2020, $\quad$ April $\left.\quad 24^{\text {th }}\right) \quad$ from https://www.youtube.com/watch?v=ekweEZcQ1 As\&feature=youtu.be

Kompas TV. Presiden Jokowi: untuk siapapun, stop korupsi! [Video file]. Retrieved (2020, April $24^{\text {th }}$ ) from https://www.youtube.com/watch?v=zr6ZQQ4Inao\&feature=youtu.be

Kompas TV. Soal natuna, Jokowi: tidak ada tawar menawar! [Video file]. Retrieved (2020, April $24^{\text {th }}$ ) from https://www.youtube.com/watch?v=w7Qlqj1_7MY\&feature=youtu.be

Kompas.com. Pidato presiden RI pada sidang paripurna MPR RI dalam rangka pelantikan presiden dan wakil presiden terpilih periode 2019-2024 Jakarta, 20 Oktober 2019. Retrieved (2019, October 19) from https://nasional.kompas.com/jeo/naskah-lengkappidato-presiden-joko-widodo-dalam-pelantikan-periode-2019-2024

Muhammad. (2011). Metode penelitian bahasa. Jogjakarta: AR-RUZZ MEDIA.

Schiffin, D. (1994). In Diane Blackmore (2002), Relevance and linguistic meaning: The semantics and pragmatics of discourse markers. New York: Cambridge University Press. 